Pesq. Vet. Bras. 36(3):181-186, março 2016 DOI: $10.1590 / \mathrm{S} 0100-736 \mathrm{X} 2016000300006$

\title{
Survival analysis of female dogs with mammary tumors after mastectomy: epidemiological, clinical and morphological aspects ${ }^{1}$
}

\author{
Maria Luíza de M. Dias² , Joanlise M. Leon Andrade ${ }^{3}$, Márcio B. de Castro ${ }^{4}$ \\ and Paula D. Galera ${ }^{2 *}$
}

\begin{abstract}
Dias M.L.M., Andrade J.M.L., Castro M.B. \& Galera P.D. 2016. Survival analysis of female dogs with mammary tumors after mastectomy: epidemiological, clinical and morphological aspects. Pesquisa Veterinária Brasileira 36(3):181-186. Departamento de Cirurgia de Pequenos Animais, Faculdade de Agronomia e Medicina Veterinária, Universidade de Brasília, Avenida L4 Norte, Asa Norte, Brasília, DF 95320-000, Brazil. E-mail: dra.paulagalera@gmail.com

Mammary gland tumors are the most common type of tumors in bitches but research on survival time after diagnosis is scarce. The purpose of this study was to investigate the relationship between survival time after mastectomy and a number of clinical and morphological variables. Data was collected retrospectively on bitches with mammary tumors seen at the Small Animal Surgery Clinic Service at the University of Brasília. All subjects had undergone mastectomy. Survival analysis was conducted using Cox's proportional hazard method. Of the 139 subjects analyzed, 68 died and 71 survived until the end of the study (64 months). Mean age was 11.76 years ( $\mathrm{SD}=2.71$ ), $53.84 \%$ were small dogs. $76.92 \%$ of the tumors were malignant, and $65.73 \%$ had both thoracic and inguinal glands affected. Survival time in months was associated with age (hazard rate ratios $[\mathrm{HRR}]=1.23, \mathrm{p}$-value $=1.4 \times 10^{-4}$ ), animal size (HRR between giant and small animals $=2.61$, $\mathrm{p}$-value $=0.02$ ), nodule size (HRR $=1.09$, $p$-value $=0.03$ ), histological type (HRR between solid carcinoma and carcinoma in a mixed tumor $=2.40$, $p$-value $=0.02$ ), time between diagnosis and surgery (TDS, with HRR $=1.21$, $\mathrm{p}$-value $=2.7 \times 10^{-15}$ ), and the interaction TDS ${ }^{*}$ follow-up time (HRR $=0.98, p$-value $\left.=1.6 \times 10^{-11}\right)$. The present study is one of the few on the subject matter. Several important covariates were evaluated and age, animal size, nodule size, histological type, TDS and TDS*follow up time were identified as significantly associated to survival time.
\end{abstract}

INDEX TERMS: Canine, mammary gland tumors, histopathology, prognosis, survival, bitches.

RESUMO-- [Análise de sobrevivência de cadela com tumores mamários após mastectomia: aspectos epidemiológicos, clínicos e morfológicos.] Os tumores da glândula mamária são o tipo mais comum de tumores em cadelas, porém, estudos sobre o tempo de sobrevida após o

\footnotetext{
${ }^{1}$ Received on June 20, 2015.

Accepted for publication on December 26, 2015.

${ }^{2}$ Departamento de Cirurgia de Pequenos Animais, Faculdade de Agronomia e Medicina Veterinária (FAV), Universidade de Brasília (UnB), Av. L4 Norte, Asa Norte, Brasília, DF 95320-000, Brazil. *Corresponding author: dra.paulagalera@gmail.com

${ }^{3}$ Departamento de Estatística, Centro de Ciências Exatas e da Terra (CCET), Universidade Federal do Rio Grande do Norte (UFRN), Av. L4 Norte, Asa Norte, Brasília, DF 95320-000, Brazil.

${ }^{4}$ Departamento de Patologia Veterinária, FAV-UnB, Av. L4 Norte, Asa Norte, Brasília, DF 95320-000, Brazil.
}

diagnóstico são escassos. Objetivou-se investigar a relação entre o tempo de sobrevida após a mastectomia, bem como variáveis clínicas e populacionais. Coletaram-se dados retrospectivos referentes a cadelas com tumores mamários atendidos no Serviço de Clínica Cirúrgica de Pequenos Animais da Universidade de Brasília e submetidas à mastectomia. A análise de sobrevida foi realizada mediante o método de Cox de risco proporcional. Dos 139 animais incluídos neste estudo, 68 morreram e 71 sobreviveram até ao final da conclusão deste traballho (64 meses). A média de idade foi de 11,76 anos ( $D P=2,71), 53,84 \%$ dos cães eram pequenos. Dentre os tumores, $76,92 \%$ eram malignos, e $65,73 \%$ tiveram as duas glândulas torácicas e a inguinal afetadas. 0 tempo de sobrevida em meses foi associado à idade (taxa de razão de risco $[\mathrm{HRR}]=1,23, p$ valor $=1.4 \times 10^{-4}$ ), o tamanho do animal (HRR entre animais gigantes e pequenos 
$=2,61, p=0,02)$, tamanho do nódulo (HRR=1,09, $p$ valor $=0,03$ ), tipo histológico (HRR entre carcinoma sólido e carcinomas em tumor misto $=2,40, p=0,02)$, tempo decorrido entre o diagnóstico e a cirurgia (TDC, com HRR $=1,21, p$ valor $=2,7 \times 10^{-15}$ ), e a interação TDC*tempo de seguimento $\left(\mathrm{HRR}=0,98, p\right.$ valor $\left.=1.6 \times 10^{-11}\right) .0$ presente estudo é um dos poucos sobre o assunto. Várias covariáveis importantes foram avaliadas e idade, tamanho do animal, o tamanho do nódulo, tipo histológico, TDC e TDC*tempo de seguimento foram identificados como significativamente associado ao tempo de sobrevida.

TERMOS DE INDEXAÇÃO: Caninos, tumores mamários, histopatologia, prognóstico, sobrevida, cadelas.

\section{INTRODUCTION}

Mammary gland tumors are the most common type of tumors in female dogs (Egenvall et al. 2005), representing about $52 \%$ of all tumor cases (Allen et al. 1986), with an annual incidence rate of 205 per 100,000 (Lana et al. 2007). Research on canine mammary tumors has grown over the past few years not only because of its increasing rate of diagnosis in veterinary medicine (Lana et al. 2007), but also because these tumors represent valuable models for breast cancer in humans (Cavalcanti \& Cassali 2006, Sorenmo et al. 2009, Uva et al. 2009).

Almost all authors report that at least $50 \%$ of the tumors are malignant while others report percentages varying from $26 \%$ to $73 \%$ (Pérez Alenza et al. 2000). Carcinomas are the most prevalent types among malignant tumors (Allen et al. 1986, Lana et al. 2007).

Approximately $60 \%$ of the tumors originate in abdominal and inguinal mammary glands, probably because these glands respond more actively to estrogen stimulus given its large parenchymatous tissue content. The appearance of these tumors in bitches under the age of two is rare, but for bitches over six years old, the incident increases substantially (Moulton 1990).

Treatment for mammary tumors involves mastectomy with clear margins. The procedure can be regional or radical depending on the spread of the tumor, and it can also be unilateral or bilateral if one or two sides are affected, respectively (White 2003). Surgery may lead to a cure in the initial stages of the disease but, in more advanced stages, the occurrence of metastasis is very common (Kurzman \& Gilbertson 1986).

In the present study we investigated the relationship between survival time after regional and/or radical mastectomy and a number of clinical and populational variables.

\section{MATERIALS AND METHODS}

Study subjects were part of a retrospective study including 143 bitches with mammary tumors seen at the Small Animal Surgery Clinic Service at the University of Brasília (UnB). All animals had undergone regional and/or radical mastectomy between January of 2004 and July of 2009. The bitches were reassessed, doing a detailed history, physical examination as palpation of axillary and popliteal lymph nodes, radiographic evaluation of the chest, every six months, in ventrodorsal projections and lateral-lateral right and left, for evaluating metastases. Animals with mammary hyperplasia or cutaneous neoplasias at the mammary region, such as lipomas and hemangiomas, were not included in the study.

This study was approved by the University of Brasília Animal Use Ethics Committee (UnbDoc no 29425/2009). Clinical and populational data were collected from medical records and as a quality control procedure, all the information collected was checked for errors.

With respect to tumor site, affected glands were classified into three groups: thoracic only (if affected glands were either cranial thoracic, caudal thoracic or cranial abdominal), inguinal only (if affected glands were either caudal abdominal or inguinal), and both thoracic and inguinal (if some were thoracic and some were inguinal).

Tumor histopathology was conducted by the UnB Veterinary Pathology Laboratory. Malignant tumors were classified (Cassali et al. 2013) into solid carcinoma(SC), tubulopapillary carcinoma (TPC; in which group were also included tubular carcinoma and papillary carcinoma), carcinoma in a mixed tumor (CMT), and fibrosarcoma (FS). Carcinomas were further characterized into Grade I, Grade II and Grade III. Evaluated the presence of tumor cell emboli in blood vessels and lymphatics, surgical margins and axillary lymph node when removed and/or inguinal lymph node. Benign tumors included adenomas, fibroadenoma (FA) and benign mixed tumors (BMT).

The Cox proportional hazards $(\mathrm{PH})$ regression model (Cox 1972) was employed to evaluate the effect of a number of covariates on survival time. In this model, the event incidence is expressed by the hazard function. It's logarithm is regressed on covariates and exponents of their estimates represent hazard rate ratios (HRR). If a covariate has a significant HRR that is greater than 1 , there is indication of a positive association between the event probability and the covariate, which means a negative association with the length of survival. Conversely, a significant HRR smaller than 1 indicates a negative association or, in other words, a protective effect (Cox 1972, Cox e Oakes 1984, Fox 2002).

The PH assumption has to be checked by testing whether interaction terms between each independent variable and survival time are significant or by testing if scaled Schoenfeld residuals for covariates are significantly correlated with a suitable transformation of time. In these cases there is evidence of non-proportional hazards (i.e. time dependent hazard) and the model has to include the significant interaction term(s). (Cox 1972, Cox e Oakes 1984, Fox 2002).

The following variables were evaluated: age at the time of diagnosis (in months), breed, dog's size (small, medium, large, and giant) use of contraception or synthetic estrogens, age at castration, affected glands (if thoracic, inguinal, or both), nodule size in $\mathrm{cm}$, mastectomy technique (thoracic regional, inguinal regional, unilateral radical, or bilateral radical), tumor histological type, presence of metastasis, time interval in months between diagnosis and surgery (TDS for short), and survival time after surgery in months.

\section{RESULTS}

During the postoperative period, defined as 3 to 64 months after surgery, 68 bitches had died. Seventy five were still alive at the end of the study. Mean age was 11.76 years (standard deviation $[\mathrm{SD}]=2.71$ years). Almost $85 \%$ were purebred, with Poodle being the most common breed (24.48\%). Most animals were of small (53.84\%) or medium (25.17\%) size. Only $39.86 \%$ had been neutered and among these, only one animal had the procedure conducted before the oestrus cycle. Mean age at castration was 8.7 years with $\mathrm{SD}=2.76$. 
With respect to clinicopathologic parameters, $65.73 \%$ of the cases had both thoracic and inguinal glands affected simultaneously. Malignant tumors were more prevalent, among which solid carcinoma (SC) was the most common type followed by carcinoma in a mixed tumor (CMT), tubulopapillary carcinoma (TPC) and fibrosarcoma (FS), showed in Table 1. Among benign tumors, benign mixed tumors (BMT) was the most frequent (16.78\% of all cases), followed by adenoma (5.59\%), and fibroadenoma (FA) $(0.7 \%)$. Twenty nine bitches had more than one diagnosis. For analytical purposes they were classified as having the more malignant type diagnosed. Unilateral radical mastectomy was the most frequent $(37.76 \%)$ treatment administered. Almost half of the animals had tumors smaller than $3 \mathrm{~cm}$ (48.95\%), while $22.38 \%$ had tumors between $3 \mathrm{~cm}$ and $5 \mathrm{~cm}$, and the remainder $28.67 \%$ had tumors greater than $5 \mathrm{~cm}$.

Table 1. Prevalence of malignant tumors in bitches

\begin{tabular}{lcccc}
\hline & SC (32,17\%) & CMT $(23,78 \%)$ & TPC $(18,88 \%)$ & FS (2,1\%) \\
\hline Grade I & $17,77 \%$ & $35,30 \%$ & $48,15 \%$ & - \\
Grade II & $62,23 \%$ & $58,82 \%$ & $44,45 \%$ & - \\
Grade III & $20 \%$ & $5,88 \%$ & $7,4 \%$ & -
\end{tabular}

$\mathrm{SC}=$ solid carcinoma, $\mathrm{CMT}=$ carcinoma in a mixed tumor, $\mathrm{TPC}=$ tubulopapillary carcinoma, FS = fibrosarcoma.

Ten bitches were diagnosed with metastatic lung and/ or axillary/inguinal lymph node during the study, and 8 of animals and 1 animal were diagnosed SC Grade III and Grade II, respectively, 1 animal was diagnosed with CMT Grade III and 1 animal was diagnosed with TPC Grade III.

Tests for the PH assumption under Cox's model showed a significant correlation between TDS residuals and time (p-value $=0.003$ ), which implied non-proportional hazards. Models were adjusted for the interaction of TDS and time to event (death) to account for the time dependent hazard.

Subjects with FS or FA histological type were removed from the analyses because of the impossibility to reliably estimate its effects given that there were no deaths in these groups. Therefore survival analyses included 139 subjects.

Table 1 shows the results of the $\mathrm{PH}$ model adjusted by a number of clinical and populational covariates. Hazard rate ratios (HRR), 95\% confidence intervals $(95 \% \mathrm{CI})$ and p-values as well as median survival time (MST) and number of deaths by number of observations per group $(D / N)$ for the significant independent variables are presented.
After adjustment for other covariates, age was significant ( $p$-value $\left.=1.4 \times 10^{-4}\right)$ with HRR estimated at $1.23(95 \%$ CI: 1.11, 1.37) indicating that each additional year of age increases the hazard rate (HR) by $23 \%$. The only significant comparison for animal size categories indicates that giant bitches had a 2.61 greater HR (95\% CI: 1.19, 5.75, p-value $=0.02$ ) than small ones. The HRR of 1.09 (95\% CI: 1.01, 1.17 , $\mathrm{p}$-value $=0.03$ ) for nodule size indicates a $9 \%$ increase in HR per $1 \mathrm{~cm}$ increase in tumor nodule size. Histological type was only significant when comparing solid carcinoma to carcinoma in a mixed tumor. The HR for solid carcinoma was 2.40 (95\% CI: 1.12, 5.17, p-value $=0.02)$, which means that solid carcinoma confers a 2.40 -fold increase in HR compared to CMT (the reference group). A positive HRR for TDS and a negative HRR for TDS*FT (both terms being significant) imply that the longer the period between diagnosis and surgery, the greater the HR but the strength of this association declines with follow-up time. Although highly significant ( $\mathrm{p}$-value $=1.6 \times 10^{-11}$ ), the magnitude of the TDS*FT interaction effect was not large (HRR=0.98) and when this term was not incorporated to the model, the main effect of TDS was not significant.

When malignancy was used as an independent variable instead of histological type, the HRR for malignant vs. benign tumors was not statistically significant ( $p$-value $=0.33$ ).

None of the other covariates (type of surgery, type of affected glands, use of contraception or synthetic estrogens, nulliparity) were statistically significant.

\section{DISCUSSION}

In this study a careful characterization of bitches that had undergone regional and/or radical mastectomy due to mammary tumors was performed and the effect of clinical and populational covariates on survival time was estimated.

Survival analyses included 139 subjects and identified age, animal size (giant vs. small), nodule size, histological type (SC vs. CMT), time between diagnosis and surgery (TDS), and the interaction between time since diagnosis and follow-up time as significantly associated with survival time, after adjustment for other covariates. Significance of the interaction term indicates non-proportional hazards. Point estimates and confidence intervals (Table 2) provide the magnitude of the effect of these variables on survival time.

Table 2. Proportional hazard analysis of the risk of death for bitches with mammary tumors after mastectomy

\begin{tabular}{|c|c|c|c|c|c|c|c|c|c|c|c|}
\hline \multirow[t]{3}{*}{ Characteristic } & \multirow{3}{*}{$\begin{array}{c}\text { Age } \\
\text { (in years) }\end{array}$} & \multicolumn{3}{|c|}{ Animal size } & \multirow{3}{*}{$\begin{array}{c}\text { Giant } \\
(>30 \mathrm{~kg})\end{array}$} & \multirow{3}{*}{$\begin{array}{l}\text { Nodule size } \\
\text { (in } \mathrm{cm} \text { ) }\end{array}$} & \multicolumn{5}{|c|}{ Histological type } \\
\hline & & \multirow{2}{*}{$\begin{array}{c}\text { Small } \\
(0-10 \mathrm{~kg})\end{array}$} & \multirow{2}{*}{$\begin{array}{c}\text { Médium } \\
(10-20 \mathrm{~kg})\end{array}$} & \multirow{2}{*}{$\begin{array}{c}\text { Large } \\
(20-30 \mathrm{~kg})\end{array}$} & & & \multicolumn{3}{|c|}{ Malignant (54/107) } & \multicolumn{2}{|c|}{ Benign (14/32) } \\
\hline & & & & & & & SC & CMT & TPC & Adenoma & BMT \\
\hline $\mathrm{D} / \mathrm{N}$ & - & $30 / 75$ & $21 / 36$ & $6 / 12$ & $11 / 16$ & - & $28 / 46$ & $12 / 34$ & $14 / 27$ & $6 / 8$ & $8 / 24$ \\
\hline $\begin{array}{c}\text { MST } \\
\text { (in months) }\end{array}$ & & 17 & 11 & 11 & 13 & - & 14 & 16 & 12 & 17 & 20 \\
\hline HRR & 1.23 & $\begin{array}{c}1.00 \\
\text { (reference) }\end{array}$ & 1.21 & 1.91 & 2.61 & 1.09 & 1.83 & 1.00 & 2.26 & 1.26 & 1.25 \\
\hline $95 \% \mathrm{CI}$ & $(1.11,1.37)$ & - & $(0.62,2.37)$ & $(0.73,5.00)$ & $(1.19,5.75)$ & $(1.01,1.17)$ & $(1.12,5.17)$ & - & $(0.99,5.14)$ & $(0.42,3.83)$ & $(0.49,3.19)$ \\
\hline $\mathrm{p}$-value & $1.4 \times 10-4$ & - & 0.58 & 0.19 & 0.02 & 0.03 & 0.02 & - & 0.05 & 0.68 & 0.65 \\
\hline
\end{tabular}

$\mathrm{D} / \mathrm{N}=\mathrm{n}^{\circ}$ of deaths $/ \mathrm{n}^{\circ}$ of observations per group, MST = median survival time after surgery, HRR = hazard rate ratio, $95 \% \mathrm{CI}=95 \%$ confidence interval, $\mathrm{SC}=$ solid carcinoma, $\mathrm{CMT}=$ carcinoma in a mixed tumor, TPC = tubulopapillary carcinoma. 
TDS and TDS*follow-up were the most significant covariates (p-values of $2.7 \times 10^{-15}$ and $1.6 \times 10^{-11}$, respectively) with a HRR of 1.21 for TDS (95\% CI: 1.16, 1.27). Significance on the interaction term, even for a small effect such as the one observed (HRR $=0.98$ ), indicates non-proportional hazards. The interpretation for a positive and a negative HRR estimate for TDS and TDS*follow-up time, respectively, is that the longer the period between diagnosis and surgery, the greater the HR but the strength of this association declines with follow-up time. It is worth mentioning that when the interaction term was not incorporated to the model, the main effect of TDS was no longer significant, which implies that the effect of TDS was averaged out over follow-up time. Therefore, the inclusion of this interaction term was necessary.

Average age at diagnosis was 11,76 years (SD $=2.71$ years). The analyses of this study showed that age is a very significant factor on survival and, based on our data, each additional year of age increases the hazard rate (HR) by $23 \%$ ( $\mathrm{p}$-value $\left.=1.4 \times 10^{-4}\right)$.

Animal size was only available in four categories and the majority of the animals were of small (53.84\%) or medium $(25.17 \%)$ size. The only statistically significant comparison was between giant and small breed animals. Weight information was only available for the surviving subjects whose average was $11.66 \mathrm{~kg}$ (SD =10.12 kg), similar to what was reported in other studies (Sonnenschein et al. 1991, Itoh et al. 2004, Lana et al. 2007, Hsu et al. 2009). However, the average weight may differ significantly from non-surviving animals. Although not available for all animals, this study suggests that weight may also be associated with survival rates. Caution is warranted when studying animal weight in the context of tumor survival given that it seems that smaller dogs in general usually live more but on the other hand weight loss may occur as a consequence of the disease progression.

There seems to be much variation in terms of histological type (Allen et al. 1986, Pérez Alenza et al. 2000, Carvalho 2006, Terzian et al. 2007). Karayannopoulou et al. (2005) observed that simple carcinomas represented $64.7 \%$ of the cases and benign mixed tumors, $20 \%$ of the benign cases, similar to this study. Hsu et al. (2009) reported that complex carcinomas and simple carcinomas represented $44 \%$ and $38.5 \%$ of the cases, respectively. In the study of Andrade et al. (2008), $52.1 \%$ of the cases were benign mixed tumors, followed by simple carcinomas (30.4\%).

Difference on survival time by histological type was only observed, in our data, when comparing SC to MTC with a HRR $=2.40$ (95\% CI: 1.12, 5.17, p-value $=0.02)$. The point estimate indicates that SC confers a 2.40 -fold increase in the HR (compared to MTC).

When we grouped histological type by their malignancy status (malignant, benign), we found no statistically significant different on survival time, which was not surprising since the HRRs for the two types of benign tumors included in the survival model (A and BMT) was not significant for any comparison with any malignant tumors. The lack of association between malignancy status and survival is probably due to early diagnosis, which minimizes the occurren- ce of metastasis. In our study only $10.49 \%$ of animals had metastasis. The proportion of cases with malignant tumors (76.92\%) observed in the present study was substantially superior to $50 \%$, as reported by Allen et al. (1986), Carvalho et al. (2006) and Horta et al. (2014), but not so different than $83,3 \%$ and $86 \%$, as reported by Dileepkumar et al. (2014) and Terzian et al. (2007), respectively.

Nodule size was also significantly associated with survival time with a HRR of 1.09 (95\% CI: 1.01,1.17, p-value = 0.03 ), indicating a $9 \%$ increase in $\mathrm{HR}$ per $1 \mathrm{~cm}$ increase in nodule size. When nodule size was categorized into smaller than $3 \mathrm{~cm}$ and greater or equal $3 \mathrm{~cm}$, the HRR was 1.99 (95\% CI: $1.09,3.62$, p-value $=0.024)$. Most of more recent studies agree that size confers prognostic significance (Sleeckx et al. 2011, Sorenmo et al. 2011, Peña et al. 2012).

Although not associated with survival rates, the distribution of types of affected glands in this study $(9.79 \%$ thoracic only, $24.48 \%$ inguinal only, and $65.73 \%$ both thoracic and inguinal glands affected) differed substantially from Galera et al. (2002) and Carvalho (2006), in which most cases $(78.94 \%$ and $69.6 \%$, respectively) had only inguinal glands affected.

Type of surgery was also not significantly associated with survival rates confirming findings from Itoh et al. (2004), in which the mortality rate for those treated with radical mastectomy $(35.7 \%)$ was very similar to that for regional mastectomy (34.8\%) among carcinoma cases. Yamagami et al. (1996) also found no statistical differences between surgery types as long as margins are clear and tumor site lymph nodes are removed.

Information on tumor differentiation was only available for some of the malignant cases. Survival analyses, restricted to these cases, showed no association between tumor differentiation and survival time. Despite the lack of significance (which could be due to smaller power to detect differences given the smaller sample size available), that was observed that $32.81 \%$ of the animals with moderately differentiated tumors survived for more than 24 months after diagnosis while no animals with poorly differentiated tumors survived for that long. Nardi (2007) observed that only $30 \%$ of the poor prognosis survived for more than 24 months after diagnosis.

Information on metastasis was only applicable to malignant cases and not significant on survival time. According to Lana et al. (2007), the risk of developing metastasis from a carcinoma within two years after mastectomy was $90 \%$ in poorly differentiated, $68 \%$ in moderately differentiated, and $24 \%$ in well differentiated cases. Karayannopoulou et al. (2005) reported somewhat different results: metastasis risk of $86.7 \%, 46.4 \%$, and $0 \%$ in poorly, moderately, and well differentiated cases, respectively. In this study, $10.4 \%$ of the cases had metastasis, of which $87.5 \%$ had solid carcinoma and $12.5 \%$ had tubulopapillary carcinoma.

Most animals had metastatic carcinoma Grade III, being a solid carcinoma was the neoplasm that most frequently metastasized, therefore has a poor prognosis and showed that histological grade might be helpful to predict survival time. These findings are similar to that reported by Peña et al. 2012. Santos et al. 2013 showed similar percentages 
local recurrence and/or distant metastases for solid and tubulopapillary carcinoma.

Several other covariates were tested and found not to be significant including use of contraception or synthetic estrogens and nulliparity.

Only $39.86 \%$ of the animals had been castrated and among these, only one animal had the procedure before of the oestrus cycle. Among castrated animals $(n=57)$, mean age at castration was 8.7 years with SD $=2.76$ (Table 1), which is considered late in terms of mammary tumor prophylaxis. Early spaying has been shown to reduce the risk of developing mammary tumors (Schneider et al. 1969).

Despite the growth of research on canine mammary tumors several aspects of the disease still need to be addressed such as prognostic factors, although some has been described (Gama et al 2008, Hsu et al. 2009, Morris et al. 2009). Studies that evaluated the association between several covariates on survival time are scarce. More studies, which include a greater number of animals in different places and in a greatest post operative period must be encouraged, to see the similarities and discrepancies.

\section{CONCLUSIONS}

The present study focused on characterizing bitches with mammary tumors and evaluating the effect of clinical and populational covariates on survival time after mastectomy.

There were identified several independent predictors of survival time including age, animal size, nodule size, histological type, time between diagnosis and surgery, and the interaction between TDS and follow-up.

A comprehensive characterization of risk and prognostic factors helps veterinarians and dog owners decide which therapeutic directions affected animals should be subjected to. Dog owners should be informed about mammary tumor prophylaxis and early diagnosis, which contributes to increased survival time if a tumor is developed.

More studies are needed to investigate new risk factors and elucidate the pathogenesis and progression of mammary tumors.

\section{REFERENCES}

Allen S.W., Prasse K.W. \& Mahaffey E.A. 1986. Cytologic differentiation of benign from malignant canine mammary tumors. Vet. Pathol. 23:649655.

Andrade A.L., Luvizotto M.C.R., Crusco S.E., Ferrari H.F. \& Lopes R.A. 2008. Avaliação imunoistoquímica da expressão da glicoproteína-P em tumores de mama de cadelas tratadas com prednisona. Vet. Zootec. 15:75-84.

Carvalho T.B. 2006. Neoplasia mamária em cadelas: caracterização histopatológica e expressão de proteínas de estresse (HSP 72). Dissertação de Mestrado, Universidade Federal de Viçosa, Viçosa, MG, p.2-35.

Cassali G.D., Lavalle G.E., Ferreira E., Estrela-Lima E., De Nardi A.B., Ghever C., Sobral R.A., Amorim R.L., Oliveira L.O., Sueiro F.A.R., Beserra H.E.O., Bertagnolli A.C., Gamba C.O., Damasceno K.A., Campos C.B., Arujo M.R., Campos L.C., Monteiro L.N., Nunes F.C., Horta R.S., Reis D.C., Luvizotto M.C.R., Magalhães G.M., Raposo J.B., Ferreira A.M.R., Tanaka N.M., Grandi F., Ubukata R., Batschinski K., Terra E.M., Salvador R.C.L., Jark P.C., Delecrodi J.E.R., Nascimento N.A., Silva D.N., Silva L.P., Ferreira K.C.R.S., Frehse M.S., Di Santis G.W., Silva E.O., Guim T.N., Kerr B., Cintra P.P., Silva F.B.F., Leite J.S., Mello M.F.V., Ferreira M.L.G., Fukumasu H., Salgado B.S. \& Torres R. 2013. Consensus for the diagnosis, prognosis and treatment of canine mammary Tumors. Braz. J. Vet. Pathol. 7:38-69.
Cavalcanti M.F. \& Cassali G.D. 2006. Fatores prognósticos no diagnóstico clínico e histopatológico dos tumores de mama em cadelas: uma revisão. Revta Clín. Vet. 61:56-64.

Cox D.R. 1972. Regression models and life tables (with discussion). J. Royal Stat. Soc. 34:187-220.

Cox D.R. \& Oakes D. 1984. Analysis of Survival Data. Chapman and Hall, London.

Dileepkumar K.M., Maiti S.K., Kumar N. \& Zama M.M.S. 2014. Occurrence of canine mammary tumours. Ind. J. Can. Pract. 6:179-183.

Egenvall A., Bonnett B.N., Ohagen P., Olson P., Hedhammar A. \& Von Euler H. 2005. Incidence of and survival after mammary tumors in a population of over 80,000 insured female dogs in Sweden from 1995 to 2002. Prev. Vet. Med. 69:109-127.

Fox, J. 2011. Cox Proportional-Hazards Regression for Survival Data in R, $\mathrm{p}$. 1-20. In: Fox, J.; Weisberg, S. An R Companion to Applied Regression. 2nd ed. Sage, Thousand Oakes. Appendix. url: https://socserv.socsci.mcmaster.ca/jfox/Books/Companion/appendix/Appendix-Cox-Regression.pdf.

Galera P.D., Freitas S.H., Oliveira J.E.B., Godoy S.S. 2002. Estudo retrospectivo da ocorrência de tumores de mama em cadelas. Revta Bras. Med. Vet. 24:252-254.

Gama A., Paredes J., Gärtner F., Alves A. \& Schmitt F. 2008. Expression of E-cadherin, P-cadherin and $\beta$-catenin in canine malignant mammary tumours in relation of clinicopathological parameters, proliferation and survival. Vet. J. 177:45-53.

Horta R.S., Lavalle G.E., Cunha R.M.C., Moura L.L., Araújo R.B. \& Cassali G.D. 2014. Influence of surgical technique on overal survival, disease free interval and new lesion development interval in dogs with mammary tumors. Adv. Breast Cancer Res. 3:38-46.

Hsu W.L., Huang H.M., Liao J.W., Wong M.L. \& Chang S.C. 2009. Increased survival in dogs with malignant mammary tumours overexpressing HER-2 protein and detection of a silent single nucleotide polymorphism in the canine HER-2 gene. Vet. J. 180:116-123.

Itoh T., Uchida K., Ishikawa K., Kushima K., Kushima E., Tamada H., Moritake T., Nakao H. \& Shii H. 2004. Clinicopathological survey of 101 canine mammary gland tumors: differences between small-breed dogs and others. J. Vet. Med. Sci. 37:345-347.

Karayannopoulou M., Kaldrymidou E., Constantinidis T.C. \& Dessiris A. 2005. Histological grading and prognosis in dogs with mammary carcinomas: application of a human grading method. J. Comp. Pathol. 133: 246-252.

Kurzman I.D. \& Gilbertson S.R. 1986. Prognostic factors in canine mammary tumors. Seminars Vet. Med. Surg. 1:25-32.

Lana S.E., Rutteman G.R. \& Withrow S.J. 2007. Tumors of the mammary gland, p.619-628. In: Withrow S.J. \& Vail D.M. (Eds), Withrow and MacEwen's Small Animal Clinical Oncology. 4th ed. Saunders Elsevier.

Morris J.S., Nixon C., King O.J.A., Morgan I.M. \& Philbey A.M. 2009. Expression of TopBP1 in canine mammary neoplasia in relation to histological type, Ki67, ER $\alpha$ and p53. Vet. J. 179:422-429.

Moulton J.E. 1990. Tumors of the mammary gland, p.518-549. In: ibid. (Ed.), Tumors in Domestic Animals. 3rd ed. University of California Press, California.

Nardi A.B. 2007. Correlação da ciclooxigenase-2 com Ki-67, P53 e Caspase-3 nas neoplasias de mama em cadelas. Tese de Doutorado, Universidade Estadual Paulista, Jaboticabal, p.1-61.

Peña L., De Andrés P.J., Clemente M., Cuesta P. \& Pérez Alenza M.D. 2012. Prognostic value of histological grading in noninflammatory canine mammary carcinomas in a prospective study with two-year follow-up: relationship with clinical and histological characteristics. Vet. Pathol. 50(1):94-105.

Pérez Alenza M.D., Peña L., Castillo N. \& Nieto A.I. 2000. Factors influencing the incidence and prognosis of canine mammary tumours. J. Small Anim. Pract. 41:287-291.

Santos A.A., Lopes C.C., Ribeiro J.R., Martins L.R., Santos J.C., Amorim I.F., Gartner F. \& Matos A.J. 2013. Identification of prognostic factors in canine mammary malignant tumours: a multivariable survival study. Vet. Res. 9:1-11. 
Schneider R., Dorn C.R. \& Taylor D.O.N. 1969. Factors influencing canine mammary cancer development and postsurgical survival. J. Natl Cancer Inst. 43:1249-1261.

Sleeckx N., Rooster H., Veldhuis Kroeze E.J.B., Van Ginneken C. \& Van Brantegem L. 2011. Canine mammary tumours, an overview. Reprod. Domest. Anim. 46:1112-1131.

Sonnenschein E.G., Glickman L.T., Goldschmidt M.H. \& McKee L.J. 1991. Body conformation, diet, and risk of breast cancer in pet dogs: a case control study. Am. J. Epidemiol. 133:694-703.

Sorenmo K.U. \& Kristiansen V.M., Cofone M.A., Shofer F.S., Breen A.M., Langeland M., Mongil C.M., Grondahl A.M., Teige J. \& Goldschmidt M.H. 2009. Canine mammary gland tumours ; a histological continuum from benign to malignant ; clinical and histopathological evidence. Vet Comp. Oncology 7:162-172.

Sorenmo K.U., Rasotto R., Zappulli V. \& Goldschmidt M.H. 2011. Development, anatomy, histology, lymphatic drainage, clinical features, and cell differentiation markers of canine mammary gland neoplasms. Vet. Pathol. 48:85-97.

Terzian A.C.B., Zuccari D.A.P.C., Pereira R.S., Pavam M.V., Ruiz C.M., Sueiro F.A.R. \& Coelho J. 2007. Avaliação da caspase-3 e ki-67 como marcadores prognósticos nas neoplasias mamárias em cadelas. Braz. J. Vet. Res. Anim. Sci. 44:96-102.

Uva P., Aurisicchio L., Watters J., Loboda A., Kulkarni A., Castle J., Palombo F., Viti V., Mesiti G., Zappulli V., Marconato L., Abramo F., Ciliberto G., Lahm A., La Monica N. \& Rinaldis E. 2009. Comparative expression pathway analysis of human and canine mammary tumors. BMC Gen. 10:1-20.

White R.A.S. 2003. Surgical treatment of specific skin disorders, p.349351. In: Slatter D.H. (Ed.), Textbook of Small Animal Surgery. Vol.1. 3rd ed. W.B. Saunders, Philadelphia.

Yamagami T., Kobayashi T., Takahashi K. \& Sugiyama M. 1996. Prognosis for canine malignant mammary tumors based on TNM and histologic classification. J. Vet. Med. Sci. 58:1079-1083. 